\title{
CHEMICAL COMPOSITION AND ANTIBACTERIAL ACTIVITY OF THE ESSENTIAL OIL OF ANTHEMIS PEDUNCULATA AND ANTHEMIS PUNCTATA
}

\author{
Hocine Laouer $^{1}$, Meriem El Kolli ${ }^{1}$, Nacera Boulaacheb ${ }^{1}$ and Salah Akkal ${ }^{2}$ \\ 1 Department of biology, University Ferhat abbas, Sétif, Algeria \\ 2 Department of chemistry, University Mentouri, Constantine, Algeria
}

\begin{abstract}
The essential oils from aerial parts of Anthemis pedunculata and Anthemis punctata (Asteraceae), obtained by hydrodistillation were analysed by gas chromatography (GC) and gas chromatography-mass spectrometry (GC-MS), and evaluated for in vitro antimicrobial activity. $\alpha$-pinène was the major compound $(25.8 \%)$ in the essential oil of A.pedunculata. This oil is characterized by other important constituents as myrcene $(8.0$ $\%)$, trans- $\beta$-farnesene $(7.8 \%)$ and cadinene $(3.0 \%)$. A. pedunculata essential oil has a moderate activity on the E. coli ATCC $25922(11 \mathrm{~mm})$ and an important activity on S. aureus ATCC $25923(45 \mathrm{~mm})$. The essential oil of A. punctata was composed in first rang by the $\beta$-pinène $(19.5 \%)$ and other constituent as the $\alpha$-pinène $(7.3 \%)$, the bornéol (5.5\%), the l'anymol (5.4\%) and the 4-aminothiophénol (4.8\%). A. punctata essential oil has a moderate activity on the E. coli ATCC $25922(11 \mathrm{~mm})$ and an important activity on S. aureus ATCC 25923 (30mm).
\end{abstract}

Keywords: Essential Oils, Antibacterial Activity, Asteraceae, Anthemis.

\section{INTRODUCTION}

Essential oils are volatile, natural, complex compounds characterized by a strong odour and are formed by aromatic plants as secondary metabolites. They are known for their antiseptic, bactericidal, virucidal and fungicidal, and medicinal properties and their fragrance; they are used in preservation of foods and as antimicrobial, analgesic, sedative, anti-inflammatory, spasmolytic and locally anesthesic remedies. Essential oils are extracted from various aromatic plants generally localized in temperate to warm countries like Mediterranean and tropical countries where they represent an important part of the traditional pharmacopoeia. They are liquid, volatile, limpid and rarely coloured, lipid soluble and soluble in organic solvents with a generally lower density than that of water. They can be synthesized by all plant organs, buds, flowers, leaves, stems, twigs, seeds, fruits, roots, wood or bark, and are stored in secretory cells, cavities, canals, epidermic cells or glandular trichomes [1].

The genus Anthemis, comprising 130 species, is a floral element of the Mediterranean [2].

The species of the Anthemis genus are widely used in the pharmaceutics, cosmetics and food industry. The flowers of the genus have welldocumented use as antiseptic and healing herbs, the main components being natural flavonoids and essential oils. The antimicrobial activity of the essential oils and different extracts from several Anthemis species has been reported before [3]. 
To the best of our knowledge, this is the first report on composition and antibacterial activity of the aerial parts of this species.

\section{MATERIAL AND METHODS}

The aerial parts of $A$. pedunculata and A. punctata were collected during the flowering period from Megress Mountain (Sétif) in May 2007 at $1720 \mathrm{~m}$ above sea level and were cut into small pieces and subjected to hydrodistillation by a Clevenger Type Apparatus.

The oil was analysed by GC on a PerkinElmer 8500 gas chromatograph with FID, fitted with a Supelcowax-10 fused silica capillary column $(30 \mathrm{~m} \times 0.32$; film thickness, $0.25 \mu \mathrm{m})$. The column temperature was programmed from $75^{\circ} \mathrm{C}$ to $200{ }^{\circ} \mathrm{C}$ at a rate of $2.5{ }^{\circ} \mathrm{C} / \mathrm{min}$. The injector and detector temperatures were programmed at $230^{\circ} \mathrm{C}$ and $300{ }^{\circ} \mathrm{C}$, respectively. Helium was used as carrier gas at flow rate of $0.6 \mathrm{ml} / \mathrm{min}$. The GC-MS analysis was carried out using two different GC-MS systems. The first was a Hewlett Packard 5973-6890 GC-MS operating on EI mode (equipped with a HP $5 \mathrm{MS} 30 \mathrm{~m} \times 0.25 \mathrm{~mm} \times 0.25 \mu \mathrm{m}$ film thickness capillary column). Helium $(1 \mathrm{ml} / \mathrm{min})$ was used as carrier gas. Temperature program: the initial temperature of the column was $60{ }^{\circ} \mathrm{C}$ (for $5 \mathrm{~min}$ ), then raised to $280^{\circ} \mathrm{C}$ within $3^{\circ} \mathrm{C} / \mathrm{min}$, and held there for $30 \mathrm{~min}$ (total time: $93.33 \mathrm{~min}$ ). The compounds were identified by comparison of their retention indexes (RI), retention times (RT) and mass spectra with those of authentic samples and/or the NIST/NBS, NIST02, Wiley 575 libraries spectra and the literature. The percentage composition of the essential oil is based on peak areas obtained without FID factor correction. The second GC-MS system analysis was a Finnegan trace GC ultra system, operating on EI mode and equipped with
$\mathrm{AT}^{\mathrm{Tm}}$ Aquawax $30 \mathrm{~m} \times 0,32 \mathrm{~mm} \times 0.25 \mu \mathrm{m}$ film thickness capillary column. Helium was used as the carrier gas, at a flow rate of $1,5 \mathrm{ml} / \mathrm{min}$ (constant flow) and Split ratio, 1:10. Temperature program: the initial temperature of the column was $60{ }^{\circ} \mathrm{C}$ (for $5 \mathrm{~min}$ ), then raised to $235^{\circ} \mathrm{C}$ within $3{ }^{\circ} \mathrm{C} / \mathrm{min}$, and held there for $30 \mathrm{~min}$ (total time: $93.33 \mathrm{~min}$ ). The MS details were as follows: source temperature, $200{ }^{\circ} \mathrm{C}$; ionization energy, $70 \mathrm{eV}$; emission, $200 \mu \mathrm{A}$; mass range, $35-650 \mathrm{Da}$; scan time, 1,25 s., scan rate $(\mathrm{amu} / \mathrm{s})$ 500,0; scans per second, 0,7974 [4].

The antibacterial activity of the oils was determined using the disc diffusion method, according to the National Committee of Clinical Laboratory Standards against three of the American Type Culture Collection (ATCC), namely: Escherichia coli (ATCC 25922), Pseudomonas aeruginosa (ATCC 27853), and Staphylococcus aureus (ATCC 25923), which were obtained from the Microbiology and Parasitology Laboratory of Setif University Hospital [5]. The tests were performed using a $18 \mathrm{~h}$ culture growth at $37^{\circ} \mathrm{C}$. The density of bacterial suspension was adjusted to a 0.5 McFarland turbidity standard (108 colony forming units $[\mathrm{CFU}] / \mathrm{ml})$. The cultures of these bacteria were grown in Mueller-Hinton Agar medium (Fluka). Sterile filter paper disks (Whatman) 6 $\mathrm{mm}$ in diameter containing $10 \mu \mathrm{L}$ of each dilution of the oil $(1 / 2,1 / 5$ and $1 / 10 \mathrm{v} / \mathrm{v}$ in absolute ethanol) were placed on the surface of the media. The plates were left for $30 \mathrm{~min}$ at room temperature to allow diffusion of the oil, and then they were incubated at $37^{\circ} \mathrm{C}$ for $24 \mathrm{~h}$. The results were recorded by measuring the zones of growth inhibition. In addition. All the experiments were performed in dublicate [6].

Positive controls were used in the assay as fosfomycin (FOS), gentamicin (GM), and 
Amikacin (AN), negative controls $(10 \mu \mathrm{L}$ ethanol) were also included in the test.

\section{RESULTS AND DISCUSSION}

\subsection{ESSENTIAL OILS ANALYSIS}

The essential oil obtained by hydrodistillation of aerial parts of $A$. pedunculata was light green while the one of $A$. punctata had a bluish colour; both of essential oils had an odour similar to those of the flowers. The yields were $0,10 \% \mathrm{w} / \mathrm{w}$ for A. pedunculata and $0,26 \% \mathrm{w} / \mathrm{w}$ for $A$. punctata. The chemical composition is summarized in Table 1 and table 2. The identified compounds represented $76,5 \%$ of all the compounds found in essential oils of A. pedunculata while $84 \%$ of all the compounds of the essential oil of A. punctata were identified. The major compound in A. pedunculata oil included: the $\alpha$-pinene $(25.8 \%)$, the myrcene $(8.0 \%)$, the tans- $\beta$-farnesen $(7.8 \%)$ and the $\beta$-pinene $(5.7 \%)$ (Table 1). The identification of the compounds was based on the comparison of their mass spctra with those of authentic samples which are available at the laboratory. The main compounds in A. punctata essential oil were the $\beta$-pinene $(19.5 \%)$, the tricyclene (9.6\%), the $\alpha$-pinene $(7.3 \%)$, the borneol (5.5\%), the anymol $(5.4 \%)$ and the 4aminothiophénol (4.8\%) (Table 2), which concord with the ulterior studies on Anthemis species as Anthemis xylopoda where the major compounds were borneol (31.80\%), 1,8cineole (5.45\%) [3] and Anthemis aciphylla where the main compounds were $\alpha$-pinene (49, $4 \%)$ and terpinen-4 ol (21, 8\%) [7].

However the major compounds found in the oil of Anthemis talyshensis were the $\alpha$ Eudesmol (18.2\%), the borneol (13.3\%), the hexadecanoic acid (9.5\%), the $\gamma$-eudesmol $(8.6 \%)$ and the elemol (7.6\%) [8]. The $\beta$ Thujone (33.7\% and $19.7 \%$, respectively) was found to be the major constituent in the leaf and flower oil of Anthemis altissima [9]. Our results differ also from those obtained by Rezaee [10], where the constituents of the essential oil of the flowers of Anthemis altissima L. var. altissima were spathulenol (18.7\%), caryophyllene oxide $(9.3 \%)$, 1eicosene $(7 \%)$ and sabinene $(6.2 \%)$, while the leafs oil contained spathulenol (18.2\%), caryophyllene oxide (9.5\%), methyl hexadecanoate $(8 \%)$ and isocaryophyllene $(7.4 \%)$.

\subsection{ANTIMICROBIAL ACTIVITY ASSAY}

Both of the essential oils showed an antibacterial activity against E. coli ATCC 25922 and S. aureus ATCC 25923, while P. aeroginosa ATCC 27853 showed a total resistance. The diameters of inhibition zones showed that the antibacterial activity is inversely proportional to the dilution. (Table 3).

The activity of the two essential oils was higher on S. aureus than the one on E. coli.

The antimicrobial properties of the two Anthemis oils are suspected to be associated with the high terpenoids contents, which has been tested previously and found to have a significant antimicrobial activity [3]. The Gram-positive strains are more sensitive than the Gram-negative bacteria;. Antimicrobial screening of some of the main components of the essential oils demonstrate that $\alpha$-pinene exhibits a weak activity [11]. Pseudomonas aeruginosa is resistant to both oils witch is reported in many studies by Rojas. [12]. Fifty two plant oils and extracts were investigated for activity against Pseudomonas aeruginosa which was inhibited by the lowest number of extracts (three) [13].

Pseudomonas aeruginosa is less susceptible to the antimicrobial properties of some essential oils than many bacteria and its tolerance is considered to be due to its outer membrane $[14,15]$. 
TABLE 1: CHEMICAL COMPOSITION OF THE ESSENTIAL OIL OF A. PEDUNCULATA

\begin{tabular}{|c|c|c|c|c|}
\hline $\begin{array}{c}\text { Chemical composition of } \\
\text { the essential oil of } \\
\text { A. pedunculata } \\
\text { Pic }\end{array}$ & $\mathrm{RT}^{*}$ & Compounds & $\mathrm{RI}^{* *}$ & $\%$ \\
\hline 1 & 3.70 & benzène & - & 0.4 \\
\hline 2 & 3.81 & cyclohexane & - & 0.2 \\
\hline 3 & 5.31 & toluène & 751 & 0.9 \\
\hline 4 & 9.93 & santolina triène & 902 & 1.7 \\
\hline 5 & 10.96 & $\alpha$-thujène & 922 & 0.3 \\
\hline 6 & 11.34 & $\alpha$-pinène & 930 & 25.8 \\
\hline 7 & 11.94 & camphène & 942 & 0.3 \\
\hline 8 & 13.05 & sabinène & 964 & 0.3 \\
\hline 9 & 13.29 & $\beta$-pinène & 969 & 5.7 \\
\hline 10 & 13.71 & $\mathrm{nd}^{* * *}$ & 977 & 0.2 \\
\hline 11 & 13.92 & myrcène & 981 & 8.0 \\
\hline 12 & 15.14 & delta-3-carène & 1005 & 0.8 \\
\hline 13 & 15.36 & benzene, 1 methyl-4-1-methylethyl & 1008 & 0.3 \\
\hline 14 & 15.53 & para cymène & 1011 & 0.4 \\
\hline 15 & 15.98 & 1,8 cinéole & 1018 & 1.4 \\
\hline 16 & 16.09 & limonène & 1020 & 2.7 \\
\hline 17 & 17.74 & $\gamma$-terpinène & 1047 & 0.5 \\
\hline 18 & 19.80 & nonanal & 1081 & 0.5 \\
\hline 19 & 19.91 & $\alpha$-terpinolene & 1083 & 0.5 \\
\hline 20 & 22.29 & sabinol & 1120 & 0.5 \\
\hline 21 & 23.91 & bornéol & 1145 & 0.7 \\
\hline 22 & 24.78 & terpinène-4-ol & 1158 & 1.0 \\
\hline 23 & 25.47 & $\alpha$-terpinéol & 1169 & 1.3 \\
\hline 24 & 26.98 & 2 methyl-6-methylène 2-7-octadienal & 1192 & 0.6 \\
\hline 25 & 37.01 & $\alpha$-longipinène & 1346 & 0.5 \\
\hline 26 & 37.71 & isopornyl propanate & 1357 & 0.3 \\
\hline 27 & 39.04 & $\beta$-bourbonène & 1378 & 0.2 \\
\hline 28 & 40.33 & bornyl ester of n-butanoic acid & 1398 & 0.8 \\
\hline 29 & 40.74 & $\alpha$-zingiberène & 1404 & 0.5 \\
\hline 30 & 41.13 & trans $\beta$-farnesène & 1411 & 7.8 \\
\hline 31 & 43.11 & $\alpha$-humulène & 1443 & 0.6 \\
\hline 32 & 44.69 & $\gamma$-cadinène & 1469 & 3.0 \\
\hline 33 & 45.61 & bicyclogermacrène & 1484 & 0.8 \\
\hline 34 & 45.71 & germacrène $\mathrm{D}$ & 1486 & 0.5 \\
\hline $35-53$ & 1 & $\mathrm{nd}^{* * *}$ & 1 & 29.1 \\
\hline
\end{tabular}

* RT: retention time,

** RI: retention index

*** nd: not determined 
Yanbu Journal of Engineering and Science Vol. 9 (2014)

TABLE 2: CHEMICAL COMPOSITION OF THE ESSENTIAL OIL OF A. PUNCTATA

\begin{tabular}{|c|c|c|c|c|}
\hline Pic & $\mathrm{RT}^{*}$ & Compounds & $\mathrm{RI}^{* *}$ & $\%$ \\
\hline 1 & 5.31 & toluène & 751 & 0.2 \\
\hline 2 & 5.54 & tricyclène & 762 & 9.6 \\
\hline 3 & 8.48 & $\mathrm{nd}^{* * *}$ & 862 & 2.0 \\
\hline 4 & 9.67 & $\mathrm{nd}^{* * *}$ & 895 & 2.8 \\
\hline 5 & 11.33 & $\alpha$-pinène & 930 & 7.3 \\
\hline 6 & 11.94 & camphène & 942 & 2.0 \\
\hline 7 & 12.36 & $\mathrm{nd}^{* * *}$ & 950 & 0.5 \\
\hline 8 & 12.55 & $\mathrm{nd}^{* * *}$ & 954 & 1.0 \\
\hline 9 & 13.36 & $\beta$-pinène & 970 & 19.5 \\
\hline 10 & 13.93 & myrcène & 981 & 3.2 \\
\hline 11 & 15.99 & 1,8 cinéole & 1019 & 1.6 \\
\hline 12 & 16.10 & limonène & 1020 & 2.5 \\
\hline 13 & 17.74 & $\gamma$-terpinène & 1047 & 0.5 \\
\hline 14 & 19.91 & $\alpha$-terpinolène & 1083 & 0.3 \\
\hline 15 & 22.06 & L-camphor & 1117 & 2.2 \\
\hline 16 & 23.32 & 3 cyclohexen-1-ol, 4-methyl 1 (1methylethyl) & 1136 & 0.5 \\
\hline 17 & 23.97 & bornéol & 1146 & 5.5 \\
\hline 18 & 24.14 & $\beta$-fenchyl alcohol & 1149 & 0.7 \\
\hline 19 & 24.78 & terpinène-4-ol & 1158 & 0.6 \\
\hline 20 & 25.48 & $\alpha$-terpinéol & 1169 & 0.7 \\
\hline 21 & 38.59 & $\alpha$-copaène & 1371 & 1.0 \\
\hline 22 & 40.69 & $\alpha$-gurjunène & 1404 & 0.7 \\
\hline 23 & 40.85 & trans $\beta$-farnesène & 1406 & 2.8 \\
\hline 24 & 41.12 & dehydro-aromadendrène & 1411 & 1.0 \\
\hline 25 & 44.51 & $\mathrm{nd}^{* * *}$ & 1466 & 1.2 \\
\hline 26 & 44.69 & germacrène D & 1469 & 2.0 \\
\hline 27 & 45.83 & $\alpha$-murolène & 1488 & 0.6 \\
\hline 28 & 46.57 & cis $\gamma$-cadinène & 1500 & 1.0 \\
\hline 29 & 47.12 & delta cadinène & 1509 & 2.3 \\
\hline 30 & 47.57 & trans $\gamma$-bisabolène & 1517 & 0.5 \\
\hline 31 & 48.36 & $\mathrm{nd}^{* * *}$ & 1531 & 2.2 \\
\hline 32 & 48.51 & 4-aminothiophénol & 1533 & 4.8 \\
\hline 33 & 50.00 & caryophellène oxide & 1559 & 1.6 \\
\hline 34 & 51.43 & $\mathrm{nd}^{* * *}$ & 1584 & 0.8 \\
\hline 35 & 51.75 & $\alpha$-ionone & 1589 & 1.0 \\
\hline 36 & 52.80 & alloocimène & 1608 & 1.5 \\
\hline 37 & 52.86 & $\mathrm{nd}^{* * *}$ & 1609 & 1.2 \\
\hline 38 & 53.01 & $\mathrm{nd}^{* * *}$ & 1612 & 2.0 \\
\hline 39 & 53.37 & $\mathrm{nd}^{* * *}$ & 1618 & 2.0 \\
\hline 40 & 54.06 & $\alpha$-cadinol & 1630 & 1.8 \\
\hline 41 & 55.80 & anymol & 1662 & 5.4 \\
\hline
\end{tabular}


TABle 3: ANTIMICROBIAL ACTIVITY OF ESSENTIAL OILS OF A. PEDUNCULATA AND A. PUNCTATA AND THE INHIBITION ZONE FORMED BY STANDARD ANTIBIOTIC DISC

\begin{tabular}{|c|c|c|c|c|c|c|c|c|c|c|}
\hline & \multirow{3}{*}{$\begin{array}{l}Q \\
B\end{array}$} & \multicolumn{6}{|c|}{ Oils } & \multirow{2}{*}{\multicolumn{3}{|c|}{ Antibiotics }} \\
\hline & & \multicolumn{3}{|c|}{ A. pedunculata } & \multicolumn{3}{|c|}{ A. punctata } & & & \\
\hline & & $1 / 2$ & $1 / 5$ & $1 / 10$ & $1 / 2$ & $1 / 5$ & $1 / 10$ & GM & AN & FOS \\
\hline E. coli ATCC25922 & - & 11 & 09 & 07 & 11 & 7.5 & 07 & 23 & 34 & 28 \\
\hline S. aureus ATCC25923 & + & 45 & 36 & 29 & 30 & 27 & 23 & 23 & 34 & 28 \\
\hline P. aeruginosa ATCC27853 & - & - & - & - & - & - & - & 23 & 34 & 33 \\
\hline
\end{tabular}

\section{REFERENCES}

[1] Bakkali F., Averbeck S., Averbeck D., and Idaomar M. Review: Biological effects of essential oils - A review. Food and Chemical Toxicology 46, 446-475, 2008.

[2] Jaime A. Teixeira da Silva. Mining the essential oils of the Anthemideae. African Journal of Biotechnology, Vol. 3 (12), pp. 706-720, 2004.

[3] Uzel, A., Guvensena A. and Cetinb E. Chemical composition and antimicrobial activity of the essential oils of Anthemis xylopoda O. Schwarz from Turkey Journal of Ethnopharmacology 95, 151-154, 2004.

[4] Liolios C., Laouer H., Boulaacheb N., Gortzi O. and Chinou I. Chemical Composition and Antimicrobial Activity of the Essential Oil of Algerian Phlomis bovei De Noé subsp. Bovei. Molecules , 12, 1-x manuscripts, 2007.

[5] Rahal K. Standardisation de L'antibiogramme en Médecine Humaine à l'Echelle Nationale selon les recommandations de l'OMS, 4ème édition, éd Ministère de la Santé, de la Population et de la Réforme Hospitalière. 2005.

[6] Benjilali B., Tantaoui-Alaraki A., Ayadi A. and Ihlal M. Method to study antimicrobial effects of essential oils: application to the antifungal activity of six Moroccan essences. Journal of food protection. 47 (10), 748-752, 1984.

[7] Hüsnü Can Baser K., Demirci B., Iscan G., Hashimoto T., Demirci F., Noma Y. and Asakawa Y. The Essential Oil Constituents and Antimicrobial Activity of Anthemis aciphylla BOISS. var. discoidea BOISS. Chem. Pharm. Bull. 54 (2) 222-225, 2006.
[8] Aghajani Z., Masoudi S.and Rustaiyan A. Volatile Oils of Anthemis talyshensis A. Fedor. And Sclerorhachis platyrachis (Boiss.) Podlech ex Rech. f. from Iran. J. Essent. Oil Res., 17, 355-357, July/August 2005.

[9] Rustaiyan, Abdolhossein, Azar, Parvis Aberoomand, Moradalizadeh, Mehran, Masoudi, Shiva, Ameri, Nazak. Volatile Constituents of Three Compositae Herbs: Anthemis altissima L. var. altissima, Conyza canadensis (L.) Cronq. and Grantina aucheri Boiss. Growing Wild in Iran.Journal of Essential Oil Research: JEOR, 2004.

[10] Rezaee, M. B., Jaimand, K. and Assareh, M. H. Chemical Constituents of the Leaf and Flower Oils from Anthemis altissima L. var. altissima from Iran. Journal of Essential Oil Research: JEOR,2006.

[11] Pintore G., Usai M., Bradesi P., Juliano C., Boatto G. Tomi E., Chessa M., Cerri1 R. and Casanova J. Chemical composition and antimicrobial activity of Rosmarinus officinalis L. oils from Sardinia and Corsica. Flavour Fragr. J., 17: 15-19, 2002.

[12] Rojas J.J., Ochoa V.J., Ocampo S.A. and Muñoz J.F. Screening for antimicrobial activity of ten medicinal plants used in Colombian folkloric medicine: A possible alternative in the treatment of non-nosocomial infections. BMC Complement Altern Med., 6: 2, 2006.

[13] Hammer K.A., Carson C.F. and Riley T.V. Antimicrobial activity of essential oils and other plant extracts. Journal of Applied Microbiology 86 (6), 985-990, 1999.

[14] Mann C.M., Cox S.D. and Markham J.L. The outer membrane of Pseudomonas aeruginosa 
NCTC 6749 contributes to its tolerance to the essential oil of Melaleuca alternifolia (tea tree oil). Letters in Applied Microbiology. 30 (4), 294-297. 2000.

[15] Papadopoulos C.J., Carson C.F., Chang B.J. and Riley T.V. Role of the MexAB-OprM Efflux Pump of Pseudomonas aeruginosa in Tolerance to Tea Tree (Melaleuca alternifolia) Oil and Its Monoterpene Components Terpinen-4-ol, 1,8Cineole, and $\alpha$-Terpineol_. APPLIED AND ENVIRONMENTAL MICROBIOLOGY, p. 1932-1935 Vol. 74, No. 6. 2008. 


\section{المكونات الكيميائية والنشاط المضاد للبكتيريا للزيوت الطبيعية المشتقة من ANTHEMISPEDUNCULATA ANTHEMISPUNCTATA}

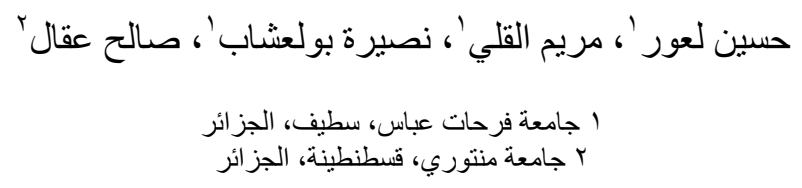

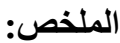

تم تحليل الزيوت العطرية من الأجزاء الهوائية لكل من Anthemis pedunculata و Anthemis gpedunculata طيف الكتلة، ـ وتم تقييمه كفترو للأثر المضاد الميكروبي بواسطة طريقة الانتشار على الوسط الصلب، تبين من

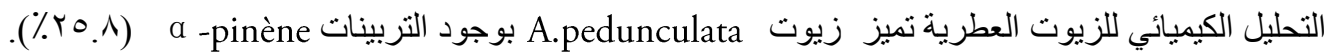
يتميز هذا الزيت بوجود المكونات الهامة الأخرى $1.0 \%$ 'myrcene

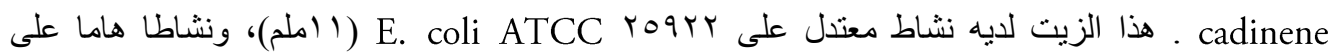
A. Punctata ينميز هذا الزيت بوجود

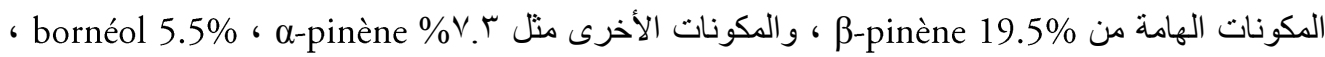

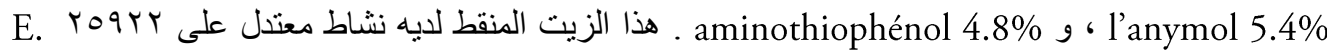
coli ATCC 